\title{
Feeling the Pinch: Kenya, Al-Shabaab, and East Africa's Refugee Crisis
}

\author{
Avery Burns
}

\begin{abstract}
Kenya currently hosts over four hundred thousand refugees. In the last two decades it has turned towards a policy of containment in an attempt to confine refugees to its two rural camps, Kakuma and Dadaab. Kenya's tolerance for the ongoing refugee problem which peaked in the 1990s due to major conflicts in the region is waning and concurrently issues of national security are growing. The Somali armed faction, Al-Shabaab, has been reportedly infiltrating Kenya's Somali refugee community. Recently, there have been reports that the government of Kenya has been covertly recruiting Somali refugees to return to Somalia to fight against Al-Shabaab. The use of refugees by Kenya to counter the threat of Al-Shabaab demonstrates a new perception of outside threats and suggests that Kenya is now willing to sacrifice ideals of humanitarianism to secure its border with Somalia. The border remains officially closed but thousands of refugees fleeing the violence in Somalia continue to pour into Kenya.

To understand why Kenya is taking such a hardened stance towards refugee populations, it is important to comprehend Kenya's strategic importance in East Africa. Secondly, in the complex relationship between internal factors and international pressures, one can discern the friction between adhering to the human rights of refugees whilst remaining a global player in the war on terror. A comparison of Kenya's past treatment of refugees to its present position suggests that the nation's most significant priority is national security, and not remaining a haven for humanitarianism.
\end{abstract}

Résumé

Le Kenya accueille actuellement plus de quatre cent mille réfugiés. Au cours des deux dernières décennies, il s'est tourné vers une politique d'endiguement dans une tentative de circonscrire les réfugiés à ses deux camps en milieu rural, Kakuma et Dadaab. La tolérance du Kenya envers le problème persistant des réfugiés, problème qui a culminé dans les années 1990 en raison de conflits majeurs dans la région, diminue au moment même où des questions de sécurité nationale prennent de l'ampleur. Les factions armées somaliennes, les Shebab, infiltreraient la communauté des réfugiés somaliens au Kenya. On rapporte récemment que le gouvernement du Kenya aurait recruté secrètement des réfugiés somaliens en vue de retourner en Somalie pour lutter contre les Shebab. L'utilisation de réfugiés par le Kenya pour contrer la menace des Shebab témoigne d'une nouvelle perception des menaces extérieures et suggère que le Kenya est maintenant prêt à sacrifier les idéaux de l'humanitarisme pour sécuriser sa frontière avec la Somalie. La frontière reste officiellement fermée, mais des milliers de réfugiés fuyant la violence en Somalie continuent d'affluer vers le Kenya.

Pour comprendre pourquoi le Kenya endurcit sa position envers les populations réfugiées, il est important de comprendre l'importance stratégique du Kenya en Afrique de l'Est. En outre, dans la relation complexe entre facteurs internes et pressions internationales, on discerne une friction entre le respect des droits humains des réfugiés et le rôle d'acteur mondial dans la guerre contre le terrorisme. Une comparaison $d u$ traitement récent des réfugiés au Kenya à la situation actuelle suggère que la sécurité nationale est la plus importante priorité de la nation. 
With the situation in Somalia deteriorating by the minute, time is of the essence. No one is feeling the pinch as much as Kenya. No one is feeling the pinch as much as Kenya. An influx of refugees and insecurity, indeed, Kenya is bearing the burden of the failed state in its neighbourhood. But Kenya's inaction could be coming to an end. ${ }^{1}$

$\mathrm{K}$ enya is dealing with several major concurrent crises: a humanitarian crisis, a political crisis, and a national security crisis. These crises reflect aspects of a national dilemma as Kenya struggles to deal with a continuous influx of refugees, major domestic political turmoil, and overt threats to its national security stemming from the Somali armed faction, Al-Shabaab. Prior to the refugee crisis beginning in the 1990s, Kenya had a laissezfaire attitude towards refugee hosting because the size of the influx was much more manageable and refugees were not deemed a major threat to national security. ${ }^{2}$ However, in the early 1990s Kenya's neighbours, mainly Sudan and Somalia, dissolved into conflict, causing hundreds of thousands of refugees to seek asylum in Kenya. The influx overwhelmed Kenya's capacity to manage the populations, and the government pushed for a policy of containing refugees in two camps, Dadaab and Kakuma. Dadaab is composed of three camps, Dagahale, Ifo and Hagadera. Dadaab is the name of the refugee site and collectively refers to all camps. At present, Dadaab is the world's largest refugee camp and is dangerously over capacity. ${ }^{3}$ Kenya continues to host refugees, albeit reluctantly, as it wishes to remain in good standing with the international community. However, its commitment to East Africa's refugee crisis is being sidelined by its own domestic strife and threats to its national security stemming from Somalia. Kenya is still reeling from the aftermath of its election violence in 2008 and is on edge as the threat from Somalia was made all the more concrete when Al-Shabaab bombed Kampala, Uganda, in July $2010 .{ }^{4}$ Consequently, Kenya's tolerance for the ongoing refugee problem which peaked in the 1990s due to major conflicts in the region is waning and concurrently issues of national security are growing.

Kenya holds a strategic geopolitical position and its humanitarian, political, and security issues are of great regional and international concern. Much of East Africa's stability depends on Kenya's stability as it is the economic epicentre for the region, and Nairobi is home to regional headquarters for embassies, non-governmental organizations (NGOs), and the United Nations. Furthermore, Kenya is of major strategic interest in the global campaign against terrorism. In 1998 a truck loaded with explosives drove into the US embassy in downtown Nairobi, killing 214 people, most of them Kenyan nationals. This was followed by a bombing of an Israeli-owned hotel in Mombasa in 2002.
These bombings were both attributed to Al-Qaeda and elevated Kenya into the international arena for the war on terror. ${ }^{5}$ It is in this context of the threat of externally based terrorism that Kenya has grown wary of armed factions, like Al-Shabaab, infiltrating refugee populations residing in the country. Al-Shabaab is an organization that has been in operation since 2006 and although its primary efforts have been to overthrow the Somali government it has also threatened to attack Kenya in hopes of annexing Kenya's North Eastern Province (NEP) into Somalia. ${ }^{6}$ Already having been a victim of terrorism, Kenya is taking the Al-Shabaab threat quite seriously.

Kenya has every right to take the Al-Shabaab threat seriously. Al-Shabaab has been infiltrating the Somali population in Kenya to recruit more fighters and gain additional support. Recently, it has been reported by Human Rights Watch and other news agencies that Kenya is retaliating by infiltrating the Somali community itself to recruit refugees to return to Somalia to fight alongside the opponents of Al-Shabaab, the Transitional Federal Government (TFG). These refugees are vulnerable and disaffected and therefore susceptible to both alleged recruitment processes. The alleged use of refugees by Kenya to counter the threat of Al-Shabaab may demonstrate a new perception of outside threats and suggests that Kenya is now willing to sacrifice ideals of humanitarianism to secure its border with Somalia. The border remains officially closed but thousands of refugees fleeing the violence in Somalia continue to pour into Kenya. These refugees are desperate for security, but Kenya is quite aware that where refugees manage to cross the border, Al-Shabaab fighters may follow.

To fully understand why Kenya is willing to take drastic measures against Al-Shabaab and use refugees as pawns in the conflict, it is important to understand Kenya's past relationship with hosting refugees and the impact of its present policies on the ongoing crisis which began in the 1990s. Secondly, Kenya is of great strategic importance to the stability of the region. Thus, it is pertinent to comprehend the core issues and key players of Kenya's domestic, regional, and international influence, which cause friction in how it deals with refugee influxes. By using refugees as proxies in conflict both Kenya and Al-Shabaab are demonstrating the strategic convenience of such vulnerable populations. Finally, Kenya's present stance on refugees illustrates that Kenya is in a position where it would rather assert its national security than honour humanitarianism because it is convinced it can no longer do both. Kenya is important to the stability and prosperity of East Africa and hence is feeling immense pressure from the international community not only to challenge the threat posed by Al-Shabaab but also to confront its major internal issues. 
Kenya is facing a serious dilemma and perceives that it cannot address its humanitarian crisis and its national security crisis simultaneously. Hence, if the allegations are true that Kenya is recruiting refugees to return to Somalia and fight Al-Shabaab, then Kenya is clearly prioritizing national security over the human rights of refugees seeking asylum within its borders.

\section{Kenya's Relations with Refugees and the Refugee Crisis of the 1990s}

The government of Kenya held a mostly laissez-faire attitude towards the refugee population prior to the refugee crisis of the 1990s and the major domestic and external security threats that it faces today. A refugee is defined as someone who is forced to flee their home due to environmental concerns, persecution, and protracted conflict. ${ }^{7}$ Generally, the term "refugee" is applied to a person who crosses international borders, while refugees who remain within the borders of their state are commonly referred to as "internally displaced persons" (IDPs.) The refugee problem was not as severe as it is today. In the 1970s and 1980s Kenya hosted a manageable number of 15,000 refugees, mostly from Uganda, who were allowed to self-settle and provided cheap labour. ${ }^{8}$ Prior to the 1990s, the government of Kenya was in charge of refugee status determination (RSD). RSD consists of a series of interviews conducted to determine whether the person qualifies for refugee status and assistance. However, the government of Kenya ceded control to the UNHCR in the early 1990s with the onset of conflict in Somalia and Sudan. There were too many refugees entering at once, which overwhelmed the government of Kenya's capacity to register refugees and maintain control over the situation. In 1992 alone, Kenya's refugee population increased from 130,000 to 400,000 people. ${ }^{9}$ Kenya's attitude towards refugees gradually shifted from indifference to great concern as it faced a major humanitarian crisis. The cross-border refugee crisis revealed to Kenya that it was incapable of assimilating and properly aiding the incoming populations. It also reminded Kenya that its borders were insecure, and that the conflict that the refugees were fleeing could potentially spill over the borders. ${ }^{10}$ Kenya was desperate for resources to deal with the influx of people during that period, and confining the refugees to camps seemed the only feasible way of providing humanitarian assistance while at the same time controlling the populations. Kenya has attempted to reassert its control over the problem of refugees, but since the 1990s, NGOs and the UNHCR remain the implementers of policy and Kenya the advisor. However, the UNHCR is still obliged to implement policies advised by Kenya, for example, ensuring that refugees are contained in Kenya's two camps.
In the beginning of the 1990s the majority of refugees arriving in Kenya did not automatically settle in camps. Many were able to self-settle until government action in the 1990s forced them to relocate to Kenya's camps, including Dadaab, Kakuma, and coastal camps near Mombasa. The refugees in the coastal camps thrived in comparison to those placed in Kakuma and Dadaab. They and the many refugees that self-settled relied on small businesses, such as selling electronics and clothing, which did not pay taxes. Powerful domestic economic segments of Mombasa and the coastal region prompted the government to close the coastal camps and eventually implement a policy of forced resettlement to Kakuma and Dadaab. ${ }^{11}$ These camps have been operational since 1991 and 1992, since the onset of the war in Somalia and the emergence of the crisis in Sudan. Kakuma refugee camp is in the Turkana district of northwest Kenya, and Dadaab is in the NEP of Kenya near Somalia. Both of these regions are among the poorest in Kenya and prone to ethnic, economic, and political strife. The Organization for African Unity (OAU) Refugee Convention requires that refugee camps should be established at a "reasonable distance" from sending nations. Kakuma is only 125 kilometres from the Sudanese border and Dadaab is only 100 kilometres from Somalia. ${ }^{12}$

Despite adhering to OAU guidelines, these distances still allow refugee communities to be heavily influenced by the events taking place in their countries of origin. Consequently, as a result of where these camps are geographically situated, their security situation is best described by this statement by an Ethiopian refugee: "In both places, Kakuma and Dadaab there are soldiers and security agents. They may kill me; those camps are so close to the border. So many times soldiers cross over to search for their opponents." ${ }^{3}$ The proximity of the camps to the sending countries clearly is an invitation for conflict to trickle over the borders. Refugee camps, in general, can be microcosms for social and political instability, and with forced migration flows gravitating towards Kenya, measures were finally put in place in an attempt to deal with the horrendous local security situation that had arisen in both camps. The populations that occupy these camps are victims, and sometimes perpetrators, of violence. According to a police officer in Dadaab, these refugees "have been brought up without justice and under the rule of the gun."14 Throughout the 1990s, as the security situation worsened, former Kenyan army officers began to serve as security officers in the camps. They were brought in to support NGO staff with major issues of security, and to develop a coordinated relationship between local government, regional police, and the military. ${ }^{15}$ Police forces in both camps have been, and still are, disproportionately 
too small to deal effectively with growing issues of security. Additionally, most of the police posted to the camps are sent there forcibly and often treat the posting as a form of punishment. ${ }^{16}$ Even if they could be made to take their jobs seriously, the security problems of both Kakuma and Dadaab would remain complex and overwhelming.

Kakuma is situated in a remote desert, a region often afflicted with famines, droughts, and general insecurity. The population in 2008 was estimated at roughly 50,000 people. ${ }^{17}$ This camp was created initially to deal with Sudanese refugees, but it quickly became a camp for over nine nationalities, including Rwandan, Burundian, Congolese, Ethiopian, and Somali. Along with inter-group friction between these various nationalities, political insecurity in Kakuma is also attributed to the relationship between the local Kenyan Turkana tribe and the refugee populations. The region has little to no economy and the Turkana are threatened by the refugees' presence. This has resulted in clashes, banditry, and cattle rustling by the Turkana against the camp and its refugees. ${ }^{18}$ The conflict between different ethnicities, tribes, and political affiliations within the camp can be attributed to refugee adjustment in Kakuma, which depends on the political, religious, or ethnic affiliations that bind them to the conflict that they have fled. The primary example of political conflict in Kakuma is that of the Sudan People's Liberation Army (SPLA), an armed faction from Sudan. The SPLA not only recruited combatants from the Sudanese refugee communities within the camp itself, but also taxed and controlled the population to a varying degree. ${ }^{19}$ The infiltration of Kakuma by the SPLA is the most significant form of infiltration that Kakuma has faced mostly because of the immense effect it had on dominating the Sudanese population at the time.

The camp has also faced infiltration from Ethiopian government forces that were there to "deal with" former Ethiopian officers. ${ }^{20}$ The government of Kenya has remained fairly unresponsive to the security issues that plague Kakuma. ${ }^{21}$ Occasionally the Kenyan military has intervened in clashes with the Turkana, but apart from that there has not been a dramatic response on its part concerning the insecurity in the region. With the Sudanese population largely repatriated back to Sudan, the noticeable problem of infiltration by armed factions in Kakuma has subsided, at least to the extent that it is no longer a perceived threat. However, the border with Sudan and Kenya remains insecure. Recent news reports suggest that the conflict with the SPLA is not over and that the group has set up bases on Kenya's side of the border. This coincides with ethnic insecurity from both sides of the border which has continuously made the establishment of a secure border extremely difficult. In February 2010, for example, several Kenyan soldiers escorting a border control task force were killed by Sudanese armed factions. ${ }^{22}$ Unfortunately, these kinds of circumstances remain true for all of Kenya's borders to the north. The infiltration in Kakuma did concern the government of Kenya but it did not provoke a major reaction because the SPLA was not deemed a direct threat to Kenya's national security, unlike the present issue with Al-Shabaab. Unlike Kakuma, infiltration in Kenya's other camp, Dadaab, has sparked not only reaction but also reprisal.

Dadaab has remained almost completely ethnically homogenous and at present is over its original combined capacity of 90,000 persons. Today, the three camps house over 260,000 refugees, most of whom are Somali, making it the largest refugee centre in the world. ${ }^{23}$ The refugees are mostly unemployed and two-thirds of the population is younger than thirty-five years old. ${ }^{24}$ Despite Kenya having closed the border to Somalia in 2007 , over 50,000 new refugees arrived in Dadaab in the first nine months of 2009. ${ }^{25}$ Dadaab, like Kakuma, has had major security issues since it first became an established camp. Apart from general insecurities related to crime, political insecurities that afflict the camp range from ethnic tension to religious extremism. When Ethiopia ousted the Union of Islamic Courts (UIC) from south-central Somalia in 2006, Kenya, threatened by the idea of UIC sympathizers fleeing into the country, officially closed the border and also began forcefully deporting asylum seekers. ${ }^{26}$ Closing the border and forceful returns marked a new chapter in Kenya's gradual shift in refugee policy. Despite the UNHCR's condemnation of Kenya's actions, the border remains closed. However, it remains extremely insecure and border security forces are fraught with corruption, and thus the technical closure of the border has done little to prevent refugees from entering the country. ${ }^{27}$

Despite being more powerful and stable than most of its neighbours, Kenya has not been economically, socially, and politically powerful enough to provide dedicated support to asylum seekers. Kenya, too, has its own population of IDPs resulting from the election violence and has had difficulty addressing their needs and finding durable solutions. Furthermore, Kenya suffers from its own internal problems such as famine, drought, and violence. Kenya may not be the most ideal haven for asylum but its geographic position makes it one of the most accessible countries for its neighbours' refugees to seek safety. International bodies, NGOs, and the United Nations pressure Kenya to welcome the refugees pouring over its borders, but there is concern about what implications these populations will have on Kenya's sovereignty and security. When huge numbers of refugees arrive in a host state, the state is often perceived to be or is actually threatened economically, environmentally, and 
culturally. ${ }^{28}$ Refugees require assistance which may financially burden the host state, and their settlements can negatively affect the surrounding environment. For example, the reliance of refugees on firewood for shelter can cause deforestation. ${ }^{29}$ These issues have caused Kenya great caution in the past and remain pertinent issues of the present. As wary as Kenya is of refugees and the problems that come with them, it has been unable to remain in full control of the crisis.

An assessment of Kenya's response to the refugee crisis from the early 1990s onwards strongly suggests that Kenya has become less tolerant of refugees seeking asylum within its boundaries. Kenya's poor political economy has made it incapable of, or unwilling to, adequately address the humanitarian concerns of the refugees crossing its many borders. This is further complicated by Kenya's serious security concerns about the state of affairs in Somalia. Consequently, Dr. Peter Kagwanja of the African Policy Institute asserts that Kenya's caution towards refugees is founded on several factors. These factors include the lack of fertile land for refugee populations, caution towards ethnic Somalis who fought in the 1960s for the annexation of the NEP of Kenya, and popular apprehension that refugees foster the spread of firearms and cause higher levels of crime. ${ }^{30}$ These fears have remained consistent from the 1960s. However, the experience of the 1990s and the real threat from Al-Shabaab have reignited these fears and caused the Kenyan government to allegedly take action. Thus Kenya, like many other states that host thousands of refugees, has implemented policies that are unfavourable in the eyes of humanitarian agencies. These policies, targeting refugee populations, are the result of the host government deeming members of certain refugee populations as potential threats to national security.

Kenya asserts that if it is to play host to refugees, they must remain under surveillance and in controlled environments: camps. ${ }^{31}$ Since the beginning of the crisis in the early 1990s, Kenya has pushed for refugees to remain in camps, but it was not until after the Al-Qaeda bombing of the US embassy in 1998 and the bombings in Mombasa in 2002 that the Kenyan government actively pursued this policy. The repression of refugee movement following these events consisted mostly of mass arrests of refugees in Nairobi. The Department of Immigration justified these acts by stating that it was an assertion of Kenya's Refugee Act and national security. Despite this public statement, there was no Kenya Refugee Act at the time. Throughout the 1990s and the period following the Al-Qaeda bombings, there was in fact a draft bill, but it was never passed by Parliament. On top of alluding to a nonexistent act, a senior immigration official noted in an interview with Guglielmo Verdirame of the London School of Economics and Political Science in 1999,
"Refugees in Kenya misbehave because they do not want to go to the camps. If someone comes to my home and I tell him where he has to sit, he has to obey, otherwise he leaves!"32 By looking at Kenya's gradual repression of refugees throughout the 1990s and following the bombings in 1998 and 2002, there are echoes of the present situation concerning Kenya's fear of refugees and the problems that come with them. Prior to the terrorist attacks, most of the restrictions only applied to refugees living in large urban centres such as Nairobi or Mombasa. Kenyan president Daniel arap Moi in 1997 issued a statement that sparked mass arrests of refugees and forced encampment:

President Moi yesterday said foreign spies and criminals masquerading as refugees had invaded Nairobi. President Moi revealed that some of these criminals were engaged in incitement at the behest of local collaborators. Emphasizing that the government will not allow foreigners to abuse the peace and stability in the country, President Moi said many of them were engaged in business as a cover-up for their evil activities. ${ }^{33}$

Perceiving refugees as potential threats is not a new perspective of the Kenyan government, as clearly demonstrated by the above statement. Closing the border to Somalia has done little to stem the flow of refugees. If anything, it has worsened the ongoing humanitarian crisis because it promotes bribery and corruption among border officials. It has also led to Kenyan police forcing refugees back into Somalia, an act that violates international law. ${ }^{34}$

The UNHCR, international governments, and NGOs have pleaded with the Kenyan government to provide more land for the Dadaab refugee camps. The severe overcrowding in Dadaab is a humanitarian crisis. There are not enough latrines or sufficient potable water due to severe issues of overcrowding. ${ }^{35}$ The human suffering that goes on in these camps is intolerable. However, particularly from the stance of Kenyans and the Kenyan government, so are the conditions in which many Kenyans in the NEP have to live in. These substandard conditions are due to a lack of available fertile land and the drought that afflicted the region in 2009. At the end of March 2010, Kenya agreed to provide more land for Dadaab's Ifo camp to accommodate 80,000 more refugees. ${ }^{36}$ This is a major contribution from Kenya. However, the fact that aid agencies and international governments have been pleading with Kenya for years to provide land reveals Kenya's hesitations in playing host to fleeing Somalis. It seems Kenya has provided this land only because of extreme international pressure and it has been argued that the land is far from the amount needed.

As previously mentioned, before Kenya was flooded with refugees in the early 1990s, refugees enjoyed a substantial 
amount of freedom, particularly freedom of movement Many refugees settled in Nairobi. Consequently, despite the policy that refugees must remain in the camps, many, particularly Ethiopians and Somalis, live illegally in Nairobi. ${ }^{37}$ Their neighbourhoods are well known and are frequently subjected to police raids. These refugees are often arrested for a lack in documentation. Kenyan Vice President of Home Affairs, Moody Awori, made a statement in 2004, pleading for all refugees in Nairobi to return to the camps:

I am asking all refugees to report to the camps and those that will be found to be in the city and other urban places without authorization will be treated like any other illegal aliens ... The government will soon mount a crackdown on these illegal aliens with a view to flushing them out. ${ }^{38}$

Since 2004, the government has been unable to flush the refugees out of Nairobi, particularly in the Somali suburb of Eastleigh. However, the police in Nairobi make their presence known with mass arrests. These sweeps often coincide with major events such as the bombing of the US embassy in 1998 and more recently after continuous threats espoused by armed factions like Al-Shabaab. ${ }^{39}$ Al-Shabaab has directly threatened Kenya which has alarmed not only Kenya itself but also the international community who deem that much of East Africa's stability rests on Kenya's stability and security.

\section{Kenya's Strategic Importance: Core Issues and Key Players}

There is a saying, "When Kenya sneezes, East Africa catches a cold." ${ }^{40}$ Kenya is the epicentre for East African economic, political, and humanitarian discourse. It is a major player regionally and internationally because, until recently, it has been one of the most prosperous and politically stable countries in East Africa. To understand the present decision to opt for national security over humanitarianism, it is important to understand Kenya's major domestic issues, which cause it to be more wary of refugees, as a result of heightened vulnerability to external attack. The international and regional community is pressuring Kenya to address these issues so that it can remain a valuable player in international discourse and a recipient of donor money. Some of these major domestic issues came to the fore in December 2007 during Kenya's federal elections. Accusations that the election was rigged provoked national civil unrest with waves of ethnic and gang-related violence. ${ }^{41}$ The election violence left nearly one thousand people dead and thousands of people displaced. It reminded the international community that Kenya, despite being stable in comparison to its troubled neighbours, is not the rock of East Africa that it was thought to be. It revealed Kenya's troubling ethnic issues and political corruption but also demonstrated how much the whole of East Africa relies on its stability.

Despite being considered a developing country, Kenya has a fairly developed infrastructure compared to its neighbours, who depend on Kenya's roads and harbours for shipping. Kenya borders five countries: Tanzania, Uganda, Sudan, Ethiopia, and Somalia. Some of these countries are highly dependent on the Northern Corridor, which is a vital road network that connects Kenya's neighbours to its busy harbour in Mombasa. During the election violence, this road was blocked and many countries were hard-pressed to receive vital shipments of fuel and essential goods. ${ }^{42}$ East African businesses also rely on Kenya because it is home to East and Central Africa's most significant stock exchange, the Nairobi Stock Exchange. ${ }^{43}$ Kenya's election violence hurt the entire region economically. Some countries were so desperate for Kenya to stabilize that even the president of Rwanda, Paul Kagame, was ready to call for a military intervention in Nairobi. ${ }^{44}$ Not only were Kenya's neighbours anxious for the violence to end, but so was the international community. Many international organizations and governments have their regional headquarters based in Nairobi. The majority of international governments' and NGOs' economic, political, and humanitarian programs for the region are headquartered in Nairobi. Many of these programs stalled as Kenya went up in flames.

Fortunately a military intervention was not necessary and the violence ceased after two months. ${ }^{45}$ At present, Kenya remains politically unstable; it has failed to address the fundamental issues of ethnic tension and political corruption. The international community continues to pressure the government to resolve these issues so that it can continue with its missions and programs. The government of Kenya has been actively trying to convince international players and its neighbours that it is legitimately trying to address its major internal issues and prevent a reoccurrence of the violence witnessed in 2007. However, continuing corruption and false promises leave many Kenyans with little to no faith in their government. For example,

President Mwai Kibaki of Kenya faced a moment of public embarrassment on 12 December 2009 when he was unable to complete his independence-day speech because of heckling from the crowd. But this was far from an opposition-organized ruckus. Some weeks earlier, his political competitor (and the prime minister) Raila Odinga could hardly speak to a gathering of his supporters who countered his slogan of chungwa! ('orange', denoting his party) with shouts of unga! (maize-flour, i.e. 'we are hungry'). ${ }^{46}$ 
To add to its difficulties, Kenya suffered from a severe drought that led to famine in September 2009. Millions of Kenyans were forced to rely on emergency food aid from the World Food Program (WFP) to confront severe food shortages. ${ }^{47}$ In context with the refugee crisis, it is difficult for Kenyans to want to help their neighbours when they seem unable to help themselves.

Furthermore, the government has also failed to address ethnic tension and severe issues of crime. These issues are compounded by the fact that Kenyans are frustrated with the government's additional failure to address the security issues stemming from the conflict in Somalia. Despite excessive military spending, the government has done little to convince its citizens that they are safe from the conflicts outside its borders. These issues are exacerbated by pressure from the international community for Kenya to address all the issues that are related to the election violence and at the same time welcome thousands of refugees coming from the Democratic Republic of Congo, Ethiopia, Sudan, and Somalia. Confronted with so many fundamental security issues, the government of Kenya evidently by its present actions deems that it must confront its greatest perceived threat, Al-Shabaab, before it can restore order within its own boundaries.

\section{Somalia and the Al-Shabaab Problem}

Al-Shabaab is a militant Islamic group that has fought against the Somali transitional government since 2006. The size of the organization is unknown, but estimates range from 6,000 to 7,000 fighters. ${ }^{48}$ Al-Shabaab has relied on guerilla tactics that include suicide bombings and assassinations. By February 2009, the group had ousted other rival armed factions and controlled most of southern Somalia. Although Al-Shabaab began as a militant group focused on domestic politics within Somalia, after open threats by Al-Shabaab against Ethiopia and now Kenya, the group has made a gradual shift from Somali national politics to East African regional politics. This shift is related to the region's support for the TFG in Mogadishu. Ethiopia's militant ousting of the Union of Islamic Courts (UIC), a group of Somali Islamists, from government in 2006 sparked threats from Al-Shabaab against Ethiopia. ${ }^{49} \mathrm{Al}$-Shabaab has openly threatened Kenya in the last year, at least in part because Kenya has attempted to combat piracy, which demonstrates Kenya's new activism against external threat. Kenya has also actively attempted to secure its border against armed factions. The International Crisis Group (ICG) states, "Al-Shabaab's threat to strike Kenya, which could reasonably be dismissed as bravado, may become real. Al-Shabaab has honed its terror tactics and skills in recent years and is now by far the deadliest guerilla movement operating in the
Horn." 50 The danger to Kenya from Al-Shabaab is no longer a perceived threat sparking precaution but a real menace. The group wants to expand its territory and now threatens the security of Kenya's NEP.

Kenya's ethnic Somali and Muslim populations mostly live in the NEP and along the southeastern coast. Although Kenyan citizens, these populations are politically and economically marginalized, making these regions prosperous recruiting grounds for groups like Al-Shabaab and Al-Qaeda. It is well known that Kenya has been used by Al-Qaeda in the past as a point of transit. ${ }^{51}$ Therefore, because Kenya has a large Muslim population that is vulnerable to recruitment and a history with terrorism, it is fair to assume that Kenya is taking the Al-Shabaab threat seriously. In the last year open threats from Al-Shabaab against Kenyan sovereignty have been increasing. For example, a song was released by the organization in January 2010 cautioning Kenya of its presence: "We have arrived at the border, we will enter Kenya, and Inshallah we will get to Nairobi ... when we get there, we will fight, we will kill, because we have weapons, enough weapons." 52 The affirmations made by refugees and NGO workers in Dadaab, one of Kenya's refugee camps, assure the Kenyan government that Al-Shabaab has not only arrived at the border, but has infiltrated the country and is spreading within. In an interview with a Dutch news agency one Somali refugee stated, "Al-Shabaab operates here in Kenya. I expect terrorists will strike here." 53 Other refugees go as far as to state that Al-Shabaab fighters come across the border not only to recruit and strengthen the organization, but also to rest from the fighting and seek treatment in Kenya's hospitals. ${ }^{54}$

Many refugees who have been interviewed on the subject acknowledge that Al-Shabaab's purpose in Kenya is to gain support in Somalia by radicalizing disaffected refugees and Kenyan Muslims to further alienate the TFG from its neighbours. ${ }^{55}$ Consequently, if the TFG falls, it is highly predictable that the horrors that go on in Somalia will spill over into Kenya, a country that is already unstable and politically fragile. This fragility is compounded by the significantly high numbers of Somali refugees living within Kenya's borders. In interviews with journalists many Somali refugees state that they do not support Al-Shabaab, as they do not believe in its use of violence as a means to implement Sharia law in Somalia. However, the group has been successful in recruiting young men and boys to return to Somalia to fight. Ahmed Hussen, president of the Canadian Somali Congress, noted that joining Al-Shabaab is a "one way ticket ... you don't come back." 56 Despite this known fact, most of these recruits are enticed to join in order to earn some income. These youths are disaffected and therefore ideologically vulnerable to the messages delivered by the recruiters to 
persuade refugees to fight in Somalia. Al-Shabaab's infiltration of Kenya's refugee community demonstrates the strategic use of refugees in war and reiterates that Kenya's borders are hugely insecure and vulnerable to attacks. If Al-Shabaab topples the TFG in Mogadishu, Kenya's territorial integrity could face severe consequences.

In the context where Kenya has been a victim of terrorism before and is under immense pressure from international actors like the UK and the US to tackle terrorist cells infiltrating the country, one can begin to piece together the present situation of Kenya's reaction to refugees. Kenya's response of repressing refugee populations outside of the camps and closing the border is not supported by the humanitarian agencies but it is a clear response to a perceived crisis and threat to national security. What is not predictable is the allegation that the Kenyan government has launched a program that recruits Somali refugees in Dadaab to return to Somalia and fight against Al-Shabaab. Testaments from refugees and reports issued by Human Rights Watch and news agencies insist that Kenyan government officials have been sending recruiters into the camp to recruit men to fight in Somalia. The recruits are told that they will be fighting with the UN and the US alongside the TFG against Al-Shabaab and they are promised financial compensation of four hundred to six hundred dollars. One refugee, Daud (age eighteen), interviewed by Human Rights Watch, said that these recruiters play not only on the refugees' fears of Al-Shabaab but also on their hopes of contributing to the rebuilding of their country. Daud said he was approached and was impressed by the thought of earning such a substantial amount of money. He was driven in a shuttle bus and dumped in a desert outside of Mombasa with other recruits. They were later picked up by Kenyan military and National Youth Service vehicles and led to a training centre. In the interview with Human Rights Watch, Daud said that on the way to the training centre their phones were confiscated and it was revealed to them that they would not be making the amount of money promised. He and a few other recruits then jumped out of the truck and escaped. ${ }^{57}$ Government officials have denied these accusations. However, local officials and officials in Somalia confirmed that these accusations are based on fact. TFG General Yusuf Dhumal in a press conference in Mogadishu stated that Somalia and Kenya have entered into an agreement to recruit soldiers from the NEP of Kenya and that these recruits were being trained outside of Mombasa. ${ }^{58}$ Despite that, he did not explain that this recruitment was targeting refugees, likely because this would be tantamount to confessing to violating human rights.

If these accusations are true, then Kenya is in violation of international human rights and may also suffer the consequences of encouraging a response from Al-Shabaab. By infiltrating Dadaab to recruit Somali refugees to fight in Somalia in response to the Al-Shabaab presence in Kenya, the government of Kenya is violating international law that states that refugee camps are meant to be purely impartial humanitarian spaces. Another violation of human rights is the allegations that some of the refugees who have been recruited have been under fifteen years old and thus are child soldiers. ${ }^{59}$ This drive compromises refugees' rights to seek asylum in a neutral territory. Furthermore, as a UN official stated to Human Rights Watch, "Recruiting Somali refugees and sending them back to Somalia to fight Al-Shabaab is an open invitation for reprisal." ${ }^{20}$ Likewise, an Al-Shabaab administrator in Dhobley, a border town in Somalia, Sheikh Mahammed Arab, issued a report that the Kenyan military has been building up along the border substantially. He stated, "We have the information about heavy military movement along the border between Somalia and Kenya. We don't know the meaning of this but we are warning of repercussions for any aggression." 61 By relying on overt and covert aggression against Al-Shabaab in these ways, Kenya could be worsening the security situation instead of aiding it. Furthermore, its reported neglect of refugees' rights to asylum may sacrifice its humanitarian integrity in the face of international players.

Dr. Francis Deng, UN Special Advisor for the Prevention of Genocide and Mass Atrocities, writes of the idea of "sovereignty as responsibility" to assert that a nation's territorial integrity may be temporarily violated in order to create shelters for refugees. The responsibility of the state, which is to protect the human rights of all people within its boundaries, is rewarded through international recognition and, in the case of Kenya, humanitarian aid. This model also asserts that a state's credibility is based on its adherence to human rights. ${ }^{62}$ The complexities of this scenario apply to Kenya. Kenya is a huge recipient of international aid and is the hub for the United Nations' regional headquarters for East Africa. Therefore, to continue receiving these benefits (for example, remaining a recipient of donor money and playing host to a large diplomatic community that stimulates its economy), Kenya has to actively engage itself in the humanitarian problems in the region. Sacrificing humanitarian integrity may seem the only realistic option for Kenya. It is not only burdened by the failed states in its neighbourhood, but it has realized that it, too, may become a failed state.

The refugee problem raised further concern following the election violence in Kenya. This produced a situation in which Kenya found itself having to deal with its own displaced persons and not just those from its neighbours. Politically vulnerable, the Kenyan government has also had to deal with external political pressure. The threat from 
Al-Shabaab to Kenya's political and territorial integrity is not a threat that Kenya can choose to ignore. Kenya's large marginalized Muslim and refugee populations make it vulnerable. By recruiting Somali refugees in Kenya, Al-Shabaab intensified the potential threat of refugees to Kenya's security as a nation-state. Like Al-Shabaab, Kenya has realized the strategic value of using refugees for their own ends. Although it originally deemed refugees a nuisance, the government of Kenya has been able to counter Al-Shabaab's strength in the Somali refugee communities by infiltrating these communities itself. By using refugees as pawns in the war against Al-Shabaab, the Kenyan government may alienate humanitarian organizations and donor nations. As previously mentioned, it could also invite reprisals from Al-Shabaab. These seem to be the risks that the government of Kenya is willing to take. Weighing the alternative of waging an overt invasion in to Somalia to tackle the Al-Shabaab threat, Kenya may also deem that being reprimanded by the international community is another risk it is willing to accept. This has led Kenya to renegotiate its stance on guarding refugee rights. Therefore, relying on refugees for a covert intervention in Somalia allows Kenya to spare its forces and at the same time confront the threat to its territorial integrity with deniability. For the Kenyan government, it may appear to be win-win situation: send the refugees back to Somalia and give them the means to take matters into their own hands, and at the same time counter the threats from Al-Shabaab. Moreover, if these allegations of Kenya recruiting within the refugee populations remain just that, allegations, then the government of Kenya can remain in good light to the international community and donors.

However, the complexity of the situation demonstrates that Kenya is a vulnerable state that is suffering from severe internal disorders; it has an enormous refugee population that continues to grow day by day; and it is being threatened by an armed faction which is fully capable of playing on the refugee crisis for the advancement of their strategy. Kenya has to address all of these issues, which may affect its security or its integrity as an international player. The biggest priority is to address its internal problems, which were revealed in the election violence of 2007. However, it is unable to fully focus on these internal problems with Al-Shabaab at its door and following the refugees as they pour in. These problems are compounded by the refugee crisis because Kenya lacks the resources to fully address the needs of these people and is continuously pressured by the international community to do something. In any case, as demonstrated, Kenya can barely feed and care for its own citizens let alone thousands of refugees who may or may not be enemies of the state.
The massive refugee crisis that began in the early 1990s has yet to end. Kenya has become intolerant of so many people pouring across its borders and seeking its assistance. It attempted to solve its problem by forcing refugees to settle in camps at the peripheries of the country; however, these refugee camps became fertile recruitment grounds for the SPLA and Al-Shabaab. Since the SPLA issue was not taken seriously, Kenya deemed the camp a UNHCR problem. Throughout the 1990s as evidence mounted that refugees were easily circumventing camp policy to live in Nairobi, and especially following the terrorist bombings of the US embassy in Nairobi and the hotel bombings in Mombasa, Kenya took a harder line on handling refugees. Once Al-Shabaab began infiltrating the country from within and threatening to attack, the government of Kenya lost its remaining tolerance for any humanitarian affairs that compromised its security. Kenya's fragility as a state and its internal strife, coupled with the threat posed by Al-Shabaab, are demonstrating that Kenya is no longer willing or able to treat its refugee crisis as a problem requiring a humanitarian solution.

As Jeff Crisp notes, quoting a UNHCR official who aptly describes the problems of Kenya's refugee camps, "You cannot create an island of security in a sea of insecurity." 63 This statement is true of the refugee camps but also of Kenya as a whole. Kenya once upon a time was seen as an island of security but times have changed. Kenya's neighbours have failed to solve their problems in the last twenty years, and if they did, new ones quickly arose. Creating an island of Kenya in this sea of insecurity is a mighty feat because Kenya is fraught with insecurity from within and from without, and is confronting an unending refugee crisis of epic proportions.

\section{Notes}

1. "National Security Council Meet to Discuss Crisis in Somalia," NTVKenya, Nairobi, 24. June 2009, http://www. youtube.com/watch? $\mathrm{v}=\mathrm{xAHrXonRGYQ}$.

2. Jeff Crisp, "A State of Insecurity: The Political Economy of Violence in Kenya's Refugee Camps," African Affairs 99. (2000): 616.

3. Gerry Simpson, "From Horror to Hopelessness," Human Rights Watch, March 29, 2009, http://www.hrw.org/en/ node/81791/section/1.

4. Judith Nabakooba, “'Somali link' as 74. World Cup Fans Die in Uganda Blasts," BBC, July 12, 2010, http://www.bbc. co.uk/news/10593771.

5. Robert Rotberg, Battling Terrorism in the Horn of Africa (Cambridge, MA: World Peace Foundation, 2005), 174. 
6. Stephanie Hanson, "Al-Shabaab," Council on Foreign Relations, February 27, 2009, http://www.cfr.org/ publication/18650/alshabaab.html.

7. Roger Zetter, "More Labels, Fewer Refugees: Remaking the Refugee Label in an Era of Globalization," Journal of Refugee Studies 20, no. 2. (June 2007): 176.

8. Crisp, "A State of Insecurity," 616.

9. Emmanuel Opoku Awuku, "Refugee Movements in Africa and the OAU Convention on Refugees," Journal of African Law 39, no. 1. (1995): 80.

10. Crisp, “A State of Insecurity, 618.

11. Ibid., 617.

12. Ibid., 623.

13. Alison Parker, Hidden in Plain View: Refugees Living without Protection in Nairobi and Kampala (New York: Human Rights Watch, 2002), 129.

14. Crisp, "A State of Insecurity," 617.

15. Ibid., 613.

16. Ibid., 615 .

17. "UNHCR-Strengthening Refugee Protection, Assistance and Support to Host Communities in Kenya: Project Proposals," UNHCR, August 1, 2008, 4, http://www.unhcr.org/ pages/4a27ceb96.html.

18. Ekuru Aukot, "It Is Better to Be a Refugee Than a Turkana in Kakuma': Revisiting the Relationship between Hosts and Refugees in Kenya," Refuge 21, no. 3. (2003), 73.

19. Crisp, "A State of Insecurity," 603.

20. Parker, Hidden in Plain View, 129.

21. Guglielmo Verdirame, "Human Rights and Refugees: The Case of Kenya," Journal of Refugee Studies 12, no. 1. (1999): 63.

22. Caroline Wafula et al., "Security Ministers to Be Grilled on Kenya Safety," Daily Nation, March 9, 2010, http://www. nation.co.ke/News/politics/-/1064/876336/-/wqi98fz/-/ index.html.

23. Simpson, "From Horror to Hopelessness," 3.

24. Letta Tayler and Chris Albin-Lackey, Kenya Recruits Somali Refugees to Fight Islamists Back Home in Somalia, Human Rights Watch, November 10, 2009, http://www.hrw.org/ en/news/2009/11/16/kenya-recruits-somali-refugees-fight -islamists-back-home-somalia.

25. World Report 2010-Kenya, Human Rights Watch, January 20, 2010, http://www.unhcr.org/refworld/docid/4b586cecc .html.

26. Simpson, "From Horror to Hopelessness," 3.

27. "Kenyans Close Border with Somalia," BBC, January 3, 2007, http://news.bbc.co.uk/2/hi/6227083.stm.

28. Robert Mandel, "Perceived Security Threat and the Global Refugee Crisis," Armed Forces and Society 24, no. 1. (Fall 1997): 82.

29. Karen Jacobsen, “Refugees' Environmental Impact: The Effect of Patterns of Settlement," Journal of Refugee Studies 10, no. 1. (1997): 19.

30. Crisp, "A State of Insecurity," 616.
31. Justin Pini, "Political Violence and the African Refugee Experience," International Affairs Review, August 13, 2008, http://www.iar-gwu.org/node/19.

32. Verdirame, "Human Rights and Refugees: The Case of Kenya," 75.

33. Ibid., 71.

34. Simpson, "From Horror to Hopelessness," 3.

35. "East Africa: Overcrowded and Desperate Camps in Somalia, Kenya and Ethiopia 'Barely Fit for Humans,' AllAfrica.com, 3 September 2009, http://allafrica.com/ stories/200909030366.html.

36. Frank Nyaikuru, "Kenya to Expand Africa’s Biggest Refugee Settlement-U.S. Official," Reuters AlertNet, http:// www.alertnet.org/db/an_art/55866/2010/03/1-131330-1 .htm.

37. Elizabeth Campbell, "Urban Refugees in Nairobi: Problems of Protection, Mechanisms of Survival, and Possibilities for Integration," Journal of Refugee Studies 19, no. 3 (2006): 399.

38. Ibid., 401.

39. Ibid.

40. Wanjohi Kabukuru, "Kenya," New African, May 1, 2009, http://www.thefreelibrary.com/When+Kenya+sneezes $+\ldots+$ despite + its + strategic + importance, + Kenya... -a0201035639.

41. Daniel Branch and Nic Cheeseman, "Democratization, Sequencing and State Failure in Africa: Lessons from Kenya," African Affairs 108, no. 430 (January 2009): 2.

42. Kabukuru, "Kenya."

43. Ibid.

44. Kezio-Musoke David, "Kalonzo Meets Kagame over Crisis," Daily Nation, February 24, 2008, http://allafrica.com/stories/200802240025.html.

45. Ibid.

46. Gerard Prunier, "The Kenya We Want," OpenDemocracy, February 3, 2009, http://www.opendemocracy.net/article/ the-kenya-we-want.

47. "Kenya Drought Worsens Hunger Risk," BBC, August 20, 2009, http://news.bbc.co.uk/2/hi/8211753.stm.

48. Daveed Gartenstein-Ross, "The Strategic Challenge of Somalia's Al-Shabaab," Middle East Quarterly 16, no. 4 (Fall 2009), http://www.meforum.org/2486/somalia-al -shabaab-strategic-challenge.

49. "Al-Shabaab-Terrorist Groups," National Counterterrorism Center (NCTC), http://www.nctc.gov/site/ groups/al_shabaab.html.

50. Daniela Kroslak, "Somalia: Militant Islamists Try to Draw Kenya into a Trap," International Crisis Group, June 26, 2009, http://www.crisisgroup.org/home/index.cfm?id=6185.

51. Rotberg, Battling Terrorism in the Horn of Africa, 20.

52. "Kenya: Al Shabaab Threaten to Attack Kenya Capital," Garowe Online, January 21, 2010, http://allafrica.com/ stories/201001210933.html.

53. Koert Lindijer, "In Kenya, Fear of Al Qaeda Ally Stokes Hatred of Somalis," NRC Handelsblad, February 2, 2010, http://www.nrc.nl/international/Features/article2473952 
.ece/In_Kenya,_fear_of_Al_Qaeda_ally_stokes_hatred_of_ Somalis? service $=$ Print.

54. "Al-Shabaab," New York Times, November 24, 2009, http://topics.nytimes.com/top/reference/timestopics/ organizations/s/al-shabab/index.html

55. Ibid.

56. "Al-Shabaab," interview by Anna Maria Tremonti, The Current, CBC Radio, Ottawa, March 10, 2010.

57. Tayler et al., "Kenya Recruits Somali Refugees to Fight Islamists Back Home in Somalia," http://www.hrw.org/ en/news/2009/11/16/kenya-recruits-somali-refugees-fight -islamists-back-home-somalia.

58. Tayler et al., "Kenya Recruits Somali Refugees to Fight Islamists Back Home in Somalia."

59. "SC/6716: Security Council Strongly Condemns Targeting of Children in Situations of Armed Conflict," Welcome to the United Nations: It's Your World, August 25, 1999, http://www.un.org/News/Press/docs/1999/19990825 .sc6716.html.
60. Tayler et al., "Kenya Recruits Somali Refugees to Fight Islamists Back Home in Somalia."

61. "Kenya: Al Shabaab Threaten to Attack Kenya Capital," Garowe Online, January 21, 2010, http://allafrica.com/ stories/printable/201001210933.html.

62. Hikaru Yamashita, Humanitarian Space and International Politics: The Creation of Safe Areas (Burlington, VT: Ashgate, 2004), 191.

63. Crisp, "A State of Insecurity," 618.

Avery Burns recently completed her MA in war studies at the Royal Military College of Canada. Prior to completing her master's degree, she lived in Nairobi, Kenya, where she completed an internship with the United Nations High Commissioner for Refugees. 